Article

\title{
Biodiesel Production from Bombacopsis glabra Oil by Methyl Transesterification Method
}

\author{
Francisca Diana da Silva Araújo ${ }^{1}$, Antonio do Nascimento Cavalcante ${ }^{2}$ (D), \\ Maria das Dores B. Sousa ${ }^{1}$, Carla Verônica Rodarte de Moura ${ }^{1}$, Mariana Helena Chaves ${ }^{1, *}$, \\ Sabria Aued-Pimentel ${ }^{3}$, Miriam Solange Fernandes Caruso ${ }^{3}$, Luimar José Tozetto ${ }^{4}$ \\ and Soane Kaline Morais Chaves 5 \\ 1 Department of Chemistry, Federal University of Piauí, 64049-550 Teresina, PI, Brazil; \\ drysana@yahoo.com.br (F.D.d.S.A); dorbarreto@hotmail.com (M.d.D.B.S.); carla@ufpi.edu.br (C.V.R.d.M.) \\ 2 Institute of Education, Science and Technology of Maranhão, 65760-000 Presidente Dutra, MA, Brazil; \\ ant_cavalcante@yahoo.com.br \\ 3 Instituto Adolfo Lutz. Division of Food Science and Chemistry, CP 1783, 01059-970 São Paulo, SP, Brazil; \\ sabria_aued@yahoo.com (S.A.-P.); micaruso@ial.sp.gov.br (M.S.F.C.) \\ 4 Development Company of the Valleys of the São Francisco and Parnaíba, Codevasf, 70830-901 Brasília, DF, \\ Brazil; luijoto@yahoo.com.br \\ 5 Department of Pharmacy, Federal University of Piauí, 64049-550 Teresina, PI, Brazil; soanek@hotmail.com \\ * Correspondence: mariana@ufpi.edu.br; Tel.: +55-86-9986-6925
}

Received: 9 July 2017; Accepted: 25 August 2017; Published: 8 September 2017

\begin{abstract}
The objective of this work was to produce methyl biodiesel from Bombacopis glabra (B. glabra) oil degummed with $\mathrm{H}_{3} \mathrm{PO}_{4}$. The methyl biodiesel was prepared in an alkaline medium, and characterized by physico-chemical parameters, thin-layer chrmatograghy (TLC), gas chromatograph (GC), (Nuclear magnetic resonance of hydrogen (H-NMR), thermogravimetry and infrared analysis. The physico-chemical parameters of biodiesel were in accordance with the limits established by National Agency of Petroleum, Natural Gas and Biofuels (ANP) Resolution 45/2014, except oxidation stability, where it was corrected with the addition of antioxidants such as TBHQ and BHT.
\end{abstract}

Keywords: oil degummed; methyl biodiesel; natural antioxidants.

\section{Introduction}

The research in biodiesel area has intensified in recent years, particularly due to the environmental advantages it presents compared to petroleum diesel. Since it is free from sulfur and aromatic compounds, it emits lower particulate content, such as hydrocarbons (HC), carbon monoxide (CO) and carbon dioxide $\left(\mathrm{CO}_{2}\right)$. It is not toxic, being biodegradable, it comes from renewable sources, and therefore, the world will benefit from the lower emission of gases contributing to the greenhouse effect $[1,2]$.

Brazil, a tropical country, has a great potential for biodiesel production, possessing large areas of productive land and a large variety of oilseed to obtain vegetable oils [3]. In some regions of the country, there are plantations with a high yield potential. In other regions, climatic conditions provide specific and almost exclusive crops, and there are regions where only the extraction would be enough to boost production on an industrial scale [3]. Thus, the study of native plants of each region is essential to evaluate their productive potential, to aggregate value to these species, and contribute to generate employment and income to the rural population.

Among the still little studied oil seeds, there is Bombacopsis glabra (Pasq.) A. Robyns, belonging to the family Malvaceae-Bombacoideae [4,5]. It is a plant known popularly as "castanha-do-maranhão", "mamorana", "castanha-da-praia", "cacau-do-maranhão", and "cacau-selvagem". It occurs in tropical 
and subtropical regions of America and Europe [6], being native in the Atlantic rainforest from Pernambuco to Rio de Janeiro, but also in the Amazon, where it grows on the banks of rivers, streams, and the Amazon estuary [7].

The B. glabra is a woody ornamental plant and can measure from 4 to 6 meters tall. The seeds of this species are the main means of propagation, with $100 \%$ germination, occurring five to ten days after sowing $[6,8]$. The flowering occurs from September to November, with fruit ripening at the beginning of the year. B. glabra can be used in the recovery of degraded areas, with a good development of seedlings in full sun and it tolerates 30 to $50 \%$ shade. Moreover, it is used as a living fence post (hedge), by "açourianas" communities of Santa Catarina Island, Brazil [8].

The fruit of B. glabra contains on average 18 seeds rich in oil. It has a pleasant taste, and is quite often consumed by humans and wild animals, yet however is poorly investigated for its economic exploitation [9]. The annual production is about 63 fruits per plant corresponding to an estimate of $570 \mathrm{~kg}$ of seeds per hectare containing a total of 400 plants [10].

Species belonging to the family Malvaceae have as a common chemical characteristic the presence of triglycerides of cyclopropenoid fatty acids (CPFA) in the oil of their almonds [5]. There are reports in the literature that compounds containing a cyclopropene ring are associated with multiple biological effects on animals including carcinogenic activities and co-carcinogenic [11-13]. Although B. glabra seeds are consumed by humans, their ingestion is not recommended due to the presence of CPFA. Due to the presence of this substance (CPFA), this oil does not compete with the edible oils for biodiesel production.

The most common cyclopropenoid fatty acids (CPFA) are malvalic and sterculic acids (Figure 1) [7]. Sterculic acid is an inhibitor of the $\Delta^{9}$-desaturase, which converts stearic acid into oleic acid, and is potentially harmful to humans in that it can alter the membrane permeability and inhibit reproduction $[12,14]$.

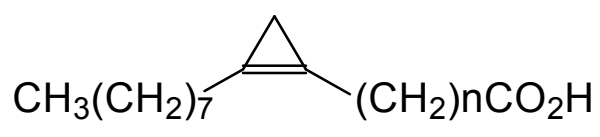

$$
\begin{aligned}
& n=6: \text { malvalic acid } \\
& n=7: \text { sterculic acid }
\end{aligned}
$$

Figure 1. Sterculic and malvalic acid chain structure.

The oil content of almonds B. glabra ranges from $34 \%$ to $50 \%$, and a composition consisting of myristic acid (from $0.0 \%$ to $0.64 \%$ ), palmitic (from $50.5 \%$ to $68.3 \%$ ), stearic (from $2.0 \%$ to $4.5 \%$ ), oleic (from $0.0 \%$ to $9.8 \%$ ), linoleic (from $8.0 \%$ to $8.9 \%$ ), linolenic acid (from $2.0 \%$ to $8.5 \%$ ), dihydrosterculic (from $0.0 \%$ to $1.5 \%$ ), malvalic (from $0.5 \%$ to $5.0 \%$ ), sterculic (from $22.0 \%$ to $28.5 \%$ ), and 2-hydroxy-sterculic (from $0.0 \%$ to $3.0 \%$ ), determined as methyl esters [7,10].

In some studies, reported in the literature about the chemical composition of B. glabra oil, the percentage of CPFA ranged from $24.5 \%$ to $34 \%$, and, in other studies there was no mention about the existence of these substances $[7,10]$. The divergence in the results of the analyses is because the CPFA are unstable and easily decompose under heating in acidic medium, depending, therefore, on the form of extraction, the conditions of derivatization and chromatographic analysis $[12,13]$.

Brazil has invested in research to diversify the raw material used in the production of biodiesel. The Sterculia striata oil which contains about 15\% CPFA [13] was investigated for the production of ethyl biodiesel [15], however, its density was above the value specified by the Brazilian Petroleum Agency.

This study aimed to extract the oil of almonds of B. glabra, to synthesize and to characterize methyl biodiesel obtained from the degummed oil with $\mathrm{H}_{3} \mathrm{PO}_{4}$. Moreover, methyl biodiesel was evaluated with synthetic antioxidants, butylated hydroxyquinone (TBHQ), and butylated hydroxytoluene (BHT), and another of natural origin, the cashew nut shell liquid (CNSL). 


\section{Results and Discussion}

\subsection{Physicochemical Parameters of Degummed Oil}

The ${ }^{1} \mathrm{H}-\mathrm{NMR}$ spectrum of the oil degummed with $\mathrm{H}_{3} \mathrm{PO}_{4}$ did not present singlet in $\delta 0.77$, corresponding to the methylene hydrogens of the cyclopropene ring showing that under these conditions there was a degradation of these groups (Figure 2), in accordance with that which was observed for oil of Sterculia striata (Malvaceae) [12].

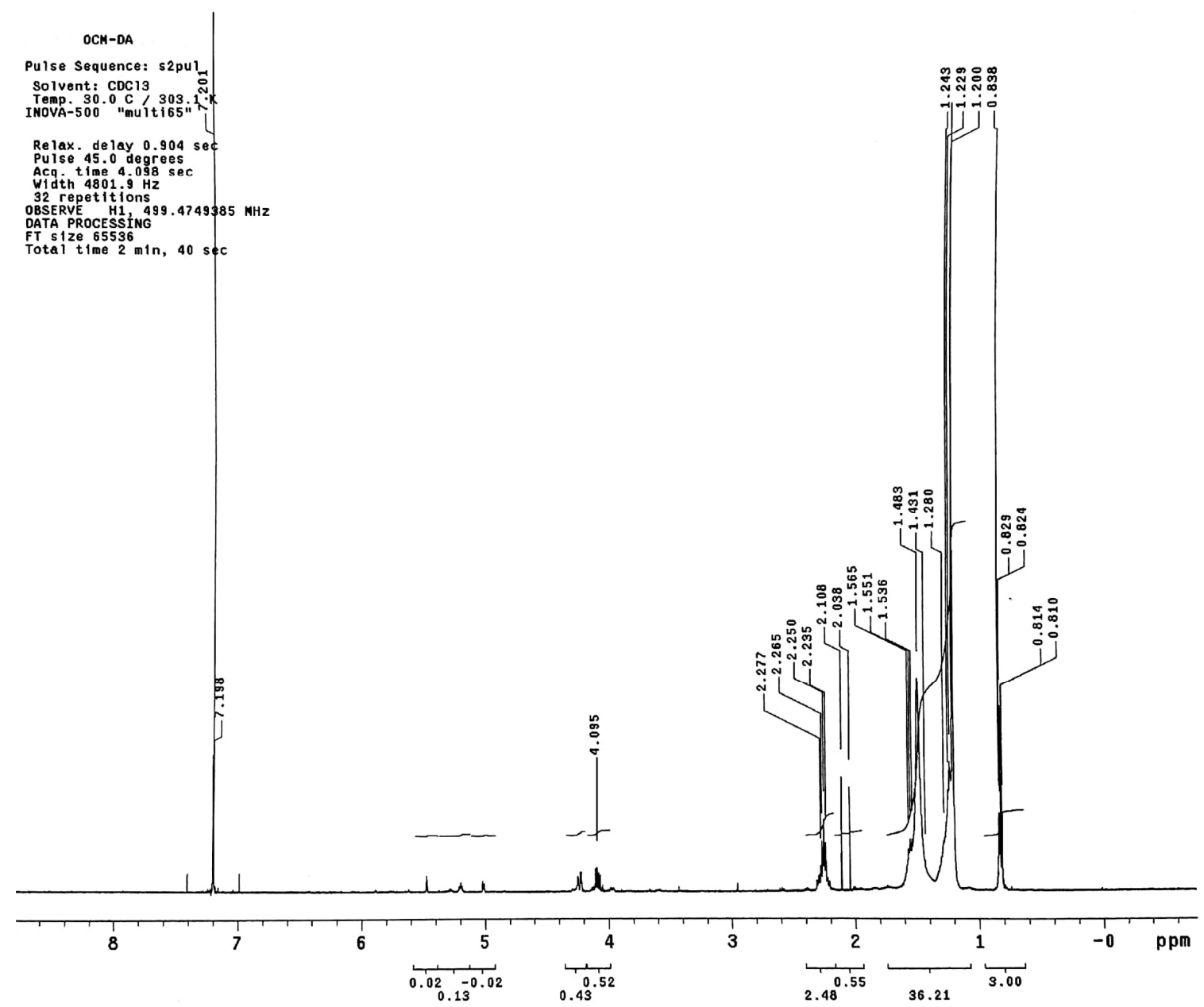

Figure 2. The ${ }^{1} \mathrm{H}-\mathrm{NMR}$ spectrum of B. glabra oil degummed with $\mathrm{H}_{3} \mathrm{PO}_{4}\left(\mathrm{CDCl}_{3}, 500 \mathrm{MHz}\right)$.

According to Table 1, the degummed oil presented an acidity level within the limits observed for refined oils, whose value is less than $0.6 \mathrm{mg} \mathrm{KOH} / \mathrm{g}$ of oil [12], being therefore suitable for conversion into biodiesel.

Table 1. Physical-chemical parameters of degummed oil of B. glabra.

\begin{tabular}{cc}
\hline Parameters & Value \\
\hline Acidity level $(\mathrm{mg} \mathrm{KOH} / \mathrm{g}$ oil $)$ & $0.5154 \pm 0.0130$ \\
Index of saponification $(\mathrm{mg} \mathrm{KOH} / \mathrm{g}$ oil $)$ & $184.21 \pm 0.98$ \\
Viscosity $40.0 \pm 0.1^{\circ} \mathrm{C}\left(\mathrm{mm}^{2} / \mathrm{s}\right)$ & $48.63 \pm 0.02$ \\
\hline
\end{tabular}

The value of the index of saponification degummed oil (Table 1) was lower than that reported in the literature (196-211 mg KOH/g oil) [10,16] and closer to palm oil (190 mg KOH/g oil) [17]. 
The B. glabra oil had a viscosity higher than that of coconut $\left(27.4 \mathrm{~mm}^{2} / \mathrm{s}\right)$, palm $\left(36.0 \mathrm{~mm}^{2} / \mathrm{s}\right)[18]$, soybean $\left(32.6 \mathrm{~mm}^{2} / \mathrm{s}\right)$, rapeseed $\left(37.0 \mathrm{~mm}^{2} / \mathrm{s}\right)$, and cotton oil $\left(33.5 \mathrm{~mm}^{2} / \mathrm{s}\right)$ [19], and below castor $\left(239.4 \mathrm{~mm}^{2} / \mathrm{s}\right)[20]$ and crambe (Crambe abyssinica) oil $\left(53.2 \mathrm{~mm}^{2} / \mathrm{s}\right)[21]$.

\subsection{Biodiesel Analysis by TLC, ${ }^{1} H-N M R$ and GC}

In biodiesel synthesis, sodium hydroxide $(\mathrm{NaOH})$ in concentrations of $0.5 \%, 0.75 \%$, and $1.0 \%$ in relation to the oil mass was used. It was observed that a low $\mathrm{NaOH}$ concentration $(0.5 \%)$ led to an incomplete reaction. On the other hand, although an excess of $\mathrm{NaOH}(1.0 \%)$ accelerates the trasesterification, it also increases the amount of water in the reaction medium in the formation of sodium methoxide step, favoring the undesired hydrolysis of biodiesel [2]. In this work, the best biodiesel yield was obtained when the $\mathrm{NaOH}$ concentration was $0.75 \%$.

The methyl biodiesel of degummed oil of B. glabra prepared with $0.75 \% \mathrm{NaOH}$ produced $90 \%$ yield, however this value is influenced in part by the formation of stable emulsions, as caused by undesirable reactions such as saponification of the methyl esters and triacylglycerols [2].

The TLC analysis of the methyl biodiesel, as produced from the degummed oil with $\mathrm{H}_{3} \mathrm{PO}_{4}$, showed that practically all the oil was transesterified (Figure 3). ${ }^{1} \mathrm{H}-\mathrm{NMR}$ spectrum (Figure 4) did not show signs characteristic of triacylglycerols between $\delta 4.10-4.40$. Moreover, the spectrum confirmed the occurrence of the transesterification reaction of the oil because it showed a singlet at $\delta 3.61$ assigned to methoxy hydrogens of ester [22]. The conversion percentage of triacylglycerols to methyl ester as determined by analysis of the ${ }^{1} \mathrm{H}-\mathrm{NMR}$ spectrum was $95 \%$. However, in the gas chromatograph (GC) analysis, the conversion percentage was $91.3 \%$, below the minimum value $(96.5 \%)$ established by the ANP Resolution 45/2014 [23].

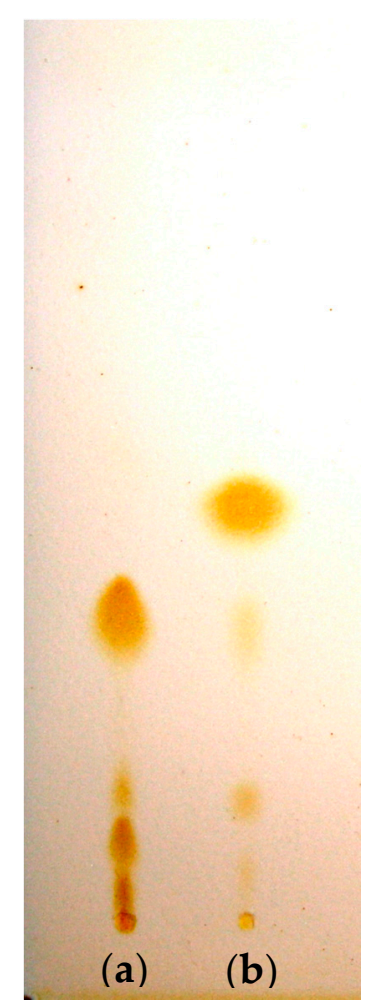

Figure 3. Thin layer chromatography (TLC) of (a) B. glabra oil and of (b) methyl biodiesel. Eluant: hexane-EtOAc (95:5); Dyeing reagent: iodine vapor. 


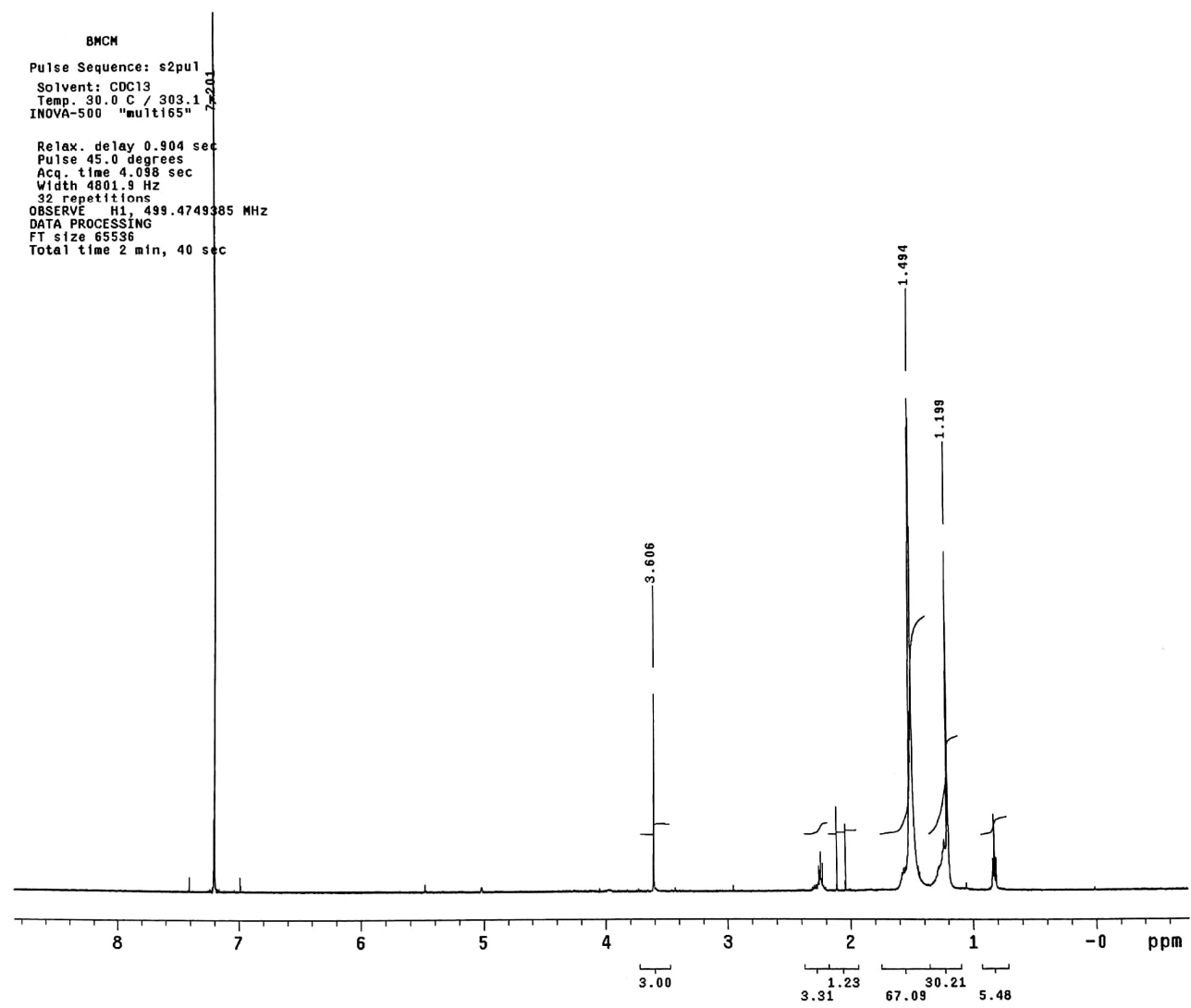

Figure 4. ${ }^{1} \mathrm{H}-\mathrm{NMR}$ spectrum of methyl biodiesel of $B$. glabra degummed oil with $\mathrm{H}_{3} \mathrm{PO}_{4}\left(\mathrm{CDCl}_{3}, 500 \mathrm{MHz}\right)$.

\subsection{Analysis in Infrared Region}

The infrared spectra of degummed oil and methyl biodiesel of B. glabra are illustrated in Figure 5. The lack of absorption bands among $2500-3300 \mathrm{~cm}^{-1}$ indicated the absence of moisture in the samples [24]. In the biodiesel spectrum, small displacements of the absorption bands were found as compared to those in the spectrum of oil: $1743 \mathrm{~cm}^{-1}$, related to the stretching vibration of $\mathrm{C}=\mathrm{O}$ of methyl esters, 1242,1172 , and $1112 \mathrm{~cm}^{-1}$ of bond C-O [24].

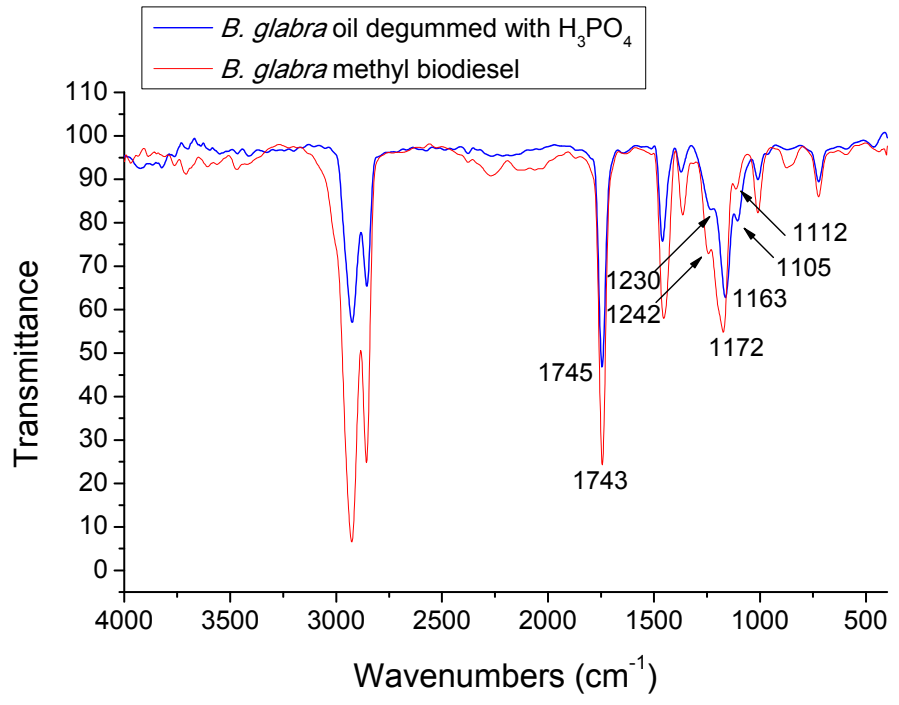

Figure 5. Infrared spectra of degummed vegetable oil and methyl biodiesel of B. glabra. 


\subsection{Thermogravimetric Analysis}

Because biodiesel is a mixture of alkyl esters, it has similar physical properties to the pure esters. Therefore, it tends to show volatility and boiling point dependency on fatty acid composition, especially the chain length and number of double bonds. Thus, to a certain biodiesel, the boiling point will be the value average of types and amounts of esters of fatty acids present $[25,26]$.

The thermogravimetric analysis has been shown as a rapid technique for measuring the boiling point and vapor pressure of many organic compounds, including vegetable oils or alkyl esters of vegetable oils. According Goodrum [25], this method does not show visible evidence that the samples of esters suffer breakdown before or during boiling. The thermogravimetry and derived thermogravimetry (TG/DTG) curve of crude oil of B. glabra, extracted with hexane at room temperature (Figure 6a) showed a weight loss of $88.23 \%$ in the temperature range 255.73 to $451.74{ }^{\circ} \mathrm{C}$, with the "onset" temperature $\left(T_{\text {onset }}\right)$ of $381.83^{\circ} \mathrm{C}$ concerning the boiling point of triacylglycerols. The second mass loss of $9.81 \%$ occurred among 451.74 to $505.47^{\circ} \mathrm{C}$, attributed to volatilization from longer chain triglycerides and/or minority constituents present in the oil [1,20]. It is noteworthy that the TG/DTG curve of B. glabra oil extracted at room temperature was very similar to that for other vegetable oils, and, despite the existence of $28.82 \pm 1.98 \%$ of CPFA as determined by ${ }^{1} \mathrm{H}-\mathrm{NMR}$ [7], thermogravimetric analysis did not show changes that could be attributed to such substances.

The degummed oil with acid showed a TG/DTG curve similar to that of crude oil (Figure $6 \mathrm{~b}$ ). The volatilization of triglycerides occurred between 261.03 to $447.20^{\circ} \mathrm{C}(88.17 \%$ mass loss) and a boiling point of $373.37^{\circ} \mathrm{C}$. The loss of mass which occurred in the range of 447.20 to $503.20^{\circ} \mathrm{C}(8.82 \%)$ was also attributed to volatilization of triglycerides with a higher molecular mass and/or minority constituents present in oil, once this process of degumming removes only partially the polar residues from oil [27]. There was still a small decay at 106.64 to $261.03^{\circ} \mathrm{C}$, with loss of mass of $2.10 \%$, which can be attributed to degradation products of CPFA.

The TG/DTG curve of methyl biodiesel of B. glabra oil degummed oil with $\mathrm{H}_{3} \mathrm{PO}_{4}$ of (Figure $6 \mathrm{c}$ ) demonstrated four thermal events. The two first intervals of mass loss observed occurred between 80.15 to $52.70{ }^{\circ} \mathrm{C}$ (loss of mass of $72.38 \%$ and $T_{\text {onset }}$ of $172.79{ }^{\circ} \mathrm{C}$ ), and 253.46 to $310.97^{\circ} \mathrm{C}$ (loss of mass of $14.72 \%$ and $T_{\text {onset }}=287.05^{\circ} \mathrm{C}$ ), being attributed to the volatilization of the methyl esters.

The TG/DTG curve of methyl biodiesel of Jatropha curcas L. oil degummed with phosphoric acid exhibits two events, being that the first occurred between 9.40 to $246.65^{\circ} \mathrm{C}$ (loss of mass of $79.47 \%$; $T_{\text {onset }}=175.81^{\circ} \mathrm{C}$ ) and the other from 246.65 to $301.14{ }^{\circ} \mathrm{C}$ (loss of mass $18.32 \%$ and $T_{\text {onset }}=287.52{ }^{\circ} \mathrm{C}$ ) [28].

Methyl biodiesel of "babaçu" (Orbignya phalerata) and soy showed a main thermal event with $T_{\text {onset }}$ corresponding to $222.1{ }^{\circ} \mathrm{C}$ [1] and $347.65{ }^{\circ} \mathrm{C}$ [25], respectively, which were attributed to the volatilization of the methyl esters. The presence of possible CPFA decomposition products likely contributed to the reduction of this value in the main event of the TG/DTG curve of B. glabra biodiesel.

The temperature interval from $310.97^{\circ} \mathrm{C}$ to $429.03^{\circ} \mathrm{C}$ and $429.03{ }^{\circ} \mathrm{C}$ to $502.44{ }^{\circ} \mathrm{C}$, with a mass loss of $10.70 \%$ and $1.28 \%$, and $T_{\text {onset }}$ of $387.91 \%$ and $463.36 \%$, respectively, were associated with the waste monoglycerides, once verified the absence of di- and triacylglycerols in the gas chromatography analysis (Table 2). It may also be associated with minority constituents in the oil, which were only removed partially in the processing biodiesel, therefore, observed with a lower content. This finding is supported by the TLC analysis, since part of the spots relative to constituents polar, observed for the degummed oil did not appear in biodiesel (Figure 3). 


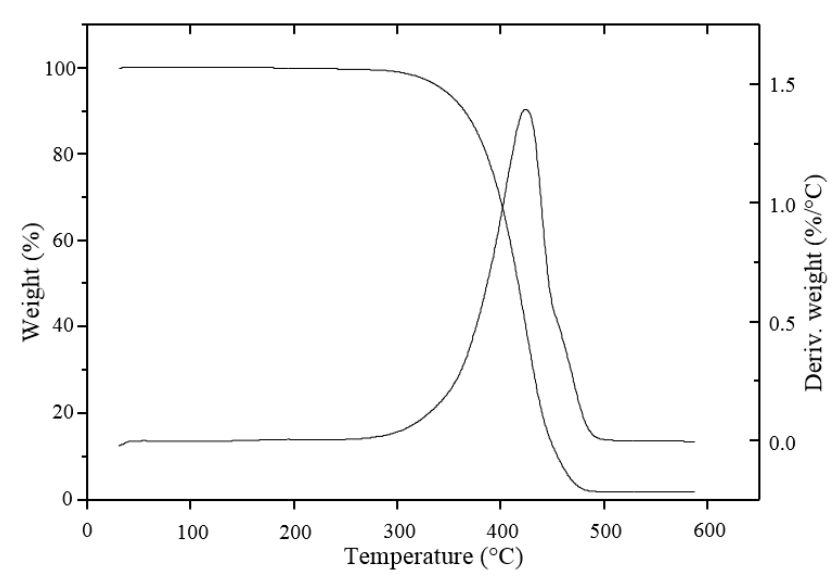

(a)

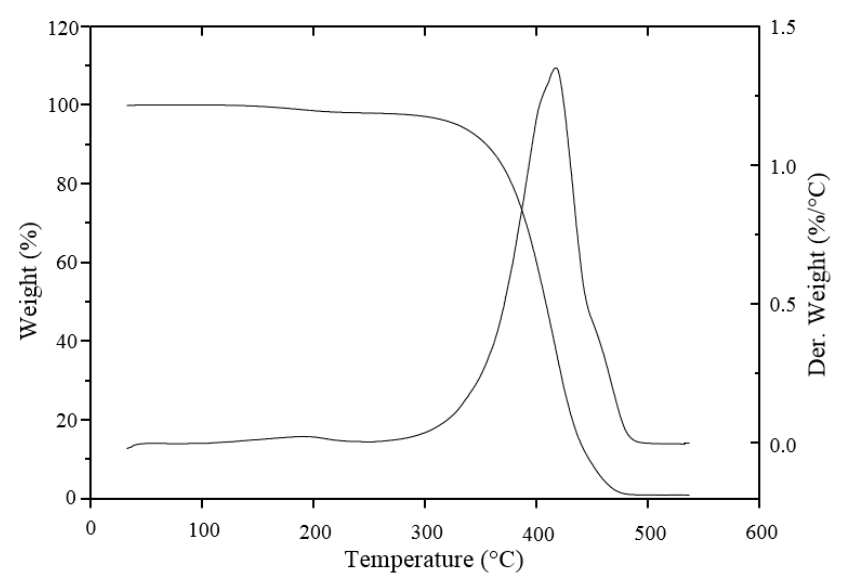

(b)

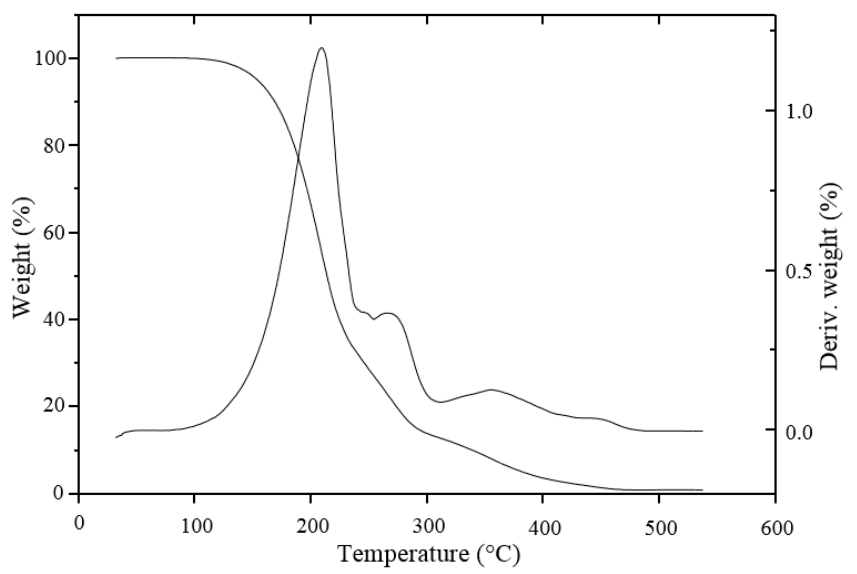

(c)

Figure 6. Thermogravimetry and derived thermogravimetry curves of oils of $B$. glabra extracted with hexane at room temperature (a) to degummed oil with $\mathrm{H}_{3} \mathrm{PO}_{4}(\mathbf{b})$ and of methyl biodiesel of degummed oil (c). 
Table 2. Physico-chemical parameters of methyl biodiesel of B. glabra.

\begin{tabular}{ccccc}
\hline Characteristic & Unit & Methods & Results & Limit ANP [23] \\
\hline Aspect & - & - & CFI & CFI \\
Specific mass at $20^{\circ} \mathrm{C}$ & $\mathrm{kg} / \mathrm{m}^{3}$ & ASTM D 4052 & 880.0 & $850-900$ \\
Kinematic viscosity at $40{ }^{\circ} \mathrm{C}$, max. & $\mathrm{mm}^{2} / \mathrm{s}$ & ASTM D 445 & 4.82 & $3-6$ \\
Water and sediments, max. & $\%$ volume & ASTM D 2709 & 0.01 & 0.050 \\
Flash Point, min. & ${ }^{\circ} \mathrm{C}$ & ASTM D 93 & 172 & 100.0 \\
Copper corrosion, $3 \mathrm{~h} 50{ }^{\circ} \mathrm{C}$, max. & - & ASTM 130 & $1 \mathrm{~b}$ & 1 \\
Filter plugging point at cold, max. & ${ }^{\circ} \mathrm{C}$ & ASTM D 6371 & 2.0 & 19 \\
Acid value, max. & $\mathrm{mg} \mathrm{KOH} / \mathrm{g}$ & IAL & 0.03 & 0.50 \\
Free Glycerol, max. & $\%$ mass & ASTM D 6584 & 0.001 & 0.02 \\
Total Glycerol, max. & $\%$ mass & ASTM D 6584 & 0.029 & 0.25 \\
Monoacylglycerol, max. & $\%$ mass & ASTM D 6584 & 0.028 & 0.70 \\
Diacylglycerol, max. & $\%$ mass & ASTM D 6584 & 0.00 & 0.20 \\
Triacylglycerol, max. & $\%$ mass & ASTM D 6584 & 0.00 & 0.20 \\
Methanol, max. & $\%$ mass & EN 41110 & 0.010 & 0.20 \\
Oxidation stability at $110{ }^{\circ} \mathrm{C}$, min. & $\mathrm{h}$ & EN 14112 & 0.76 & 8 \\
\hline
\end{tabular}

CFI: Clear and free of impurities; IAL: Institute Adolfo Lutz; ANP: National Agency of Petroleum, Natural Gas and Biofuels; ASTM: American Society of Testing and Materials; and, EN: European Normalisation.

\subsection{Physico-Chemical Parameters}

The physico-chemical parameters of B. glabra biodiesel (Table 2) are within the limits established in the ANP Resolution 45/2014 [23], with the exception of the oxidation stability at $110{ }^{\circ} \mathrm{C}(0.76 \mathrm{~h})$ that may be corrected with the addition of antioxidants to meet specifications. The low oxidation stability of biodiesel was in agreement with the low thermal stability in the thermogravimetric analysis. This behavior must be due to the presence of degradation products of CPFA in the degummed oil with $\mathrm{H}_{3} \mathrm{PO}_{4}$ and hence the biodiesel.

The percentage of monoacylglycerol and the absence of di and triacylglycerol in GC analysis, associated with low levels of total glycerin, showed that there was a high rate of conversion of oil in methyl ester.

\subsection{Addition Effect of Antioxidants in Stability from Methyl Biodiesel of B. glabra}

Aiming to increase the oxidation stability of the B. glabra, biodiesel tests were carried out using synthetic antioxidants, butylated hydroxyquinone (TBHQ), and butylated hydroxytoluene (BHT), and another of natural origin, the cashew nut shell liquid (CNSL), as shown in Figure 7.<smiles>Cc1cc(C(C)(C)C)c(O)c(C(C)(C)C)c1</smiles>

BHT<smiles>CC(C)(C)c1cc(O)ccc1O</smiles>

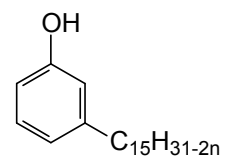

Cardanol

Anacardic acid

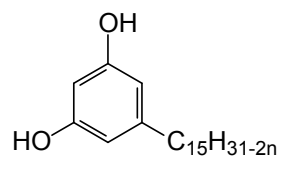

Cardol

$$
\mathrm{n}=0 ; \mathrm{n}=1 \Delta^{8}, \mathrm{n}=2 \Delta^{8,11}, \mathrm{n}=3 \Delta^{8,11,14}
$$

Figure 7. Chemical structure of synthetic antioxidants (butylated hydroxytoluene (BHT) and butylated hydroxyquinone (TBHQ)) and the main constituents of the cashew nut shell liquid (CNSL).

TBHQ and BHT are primary antioxidants that interrupt oxidative reactions in the chain, by the donation of hydrogens atoms from phenolic hydroxyl to the free radicals of esters, later becoming free 
radical, which stabilized by resonance without starting or spreading the oxidation [29,30]. The potential of these antioxidants in the stabilization of soy, palm, and jatropha biodiesel has been verified by several researchers [29,31-34].

CNSL is comprised of meta-alkylphenols (anacardic acid, cardanol and cardol) (Figure 7), which act as free radical scavengers and sometimes as metal chelators, in steps of initiation and the spread of the oxidation process (Figure 8) [29], and may be used as an antioxidant of fuel and lubricant [35]. According to literature reports, an improvement of the thermal stability of the oil and castor biodiesel is observed when using CNSL as an additive [35].

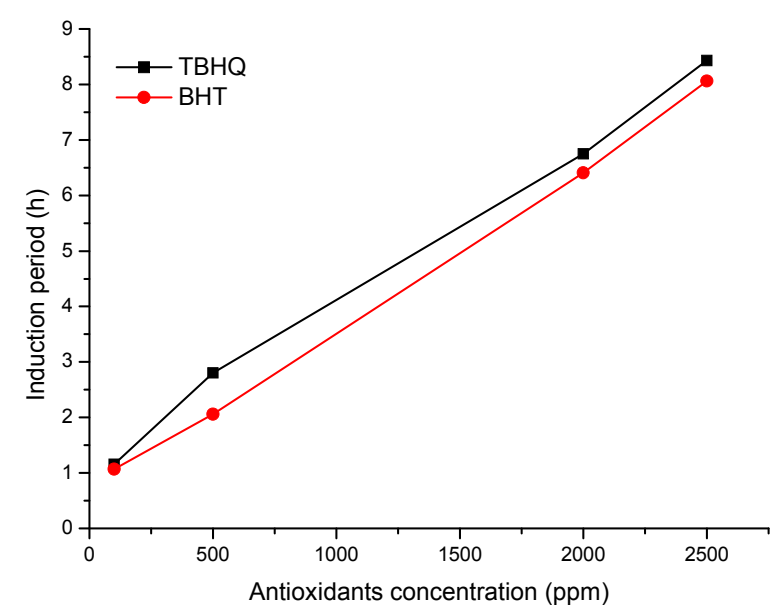

Figure 8. Effect of concentrations of TBHQ and BHT in the induction period of methyl biodiesel of B. glabra.

TBHQ and BHT were effective in an increase of induction period of the methyl biodiesel (Figure 8). An addition of $2500 \mathrm{ppm}$ of both antioxidants was necessary to reach the specification of this parameter, as required by ANP Resolution 45/2014, given that the biodiesel present with stability only $0.76 \mathrm{~h}$.

It was observed that in the concentrations studied of TBHQ and BHT, the induction period was significantly similar. However, research showed that in the soybean biodiesel the induction period was only $0.16 \mathrm{~h}$, and TBHQ presented a greater potential of stability. TBHQ was utilized in higher concentrations and showed differences in stabilization, when compared to BHT [29].

In Figure 9 and Table 3, the induction period gradually increases with the use of high concentrations of CNSL. In addition, this increase remained practically constant above $2 \%$ of antioxidant. In these concentrations, the physico-chemical characteristics of biodiesel may be compromised. The results show that CNSL is not appropriate to be used as an antioxidant additive of biodiesel of B. glabra.

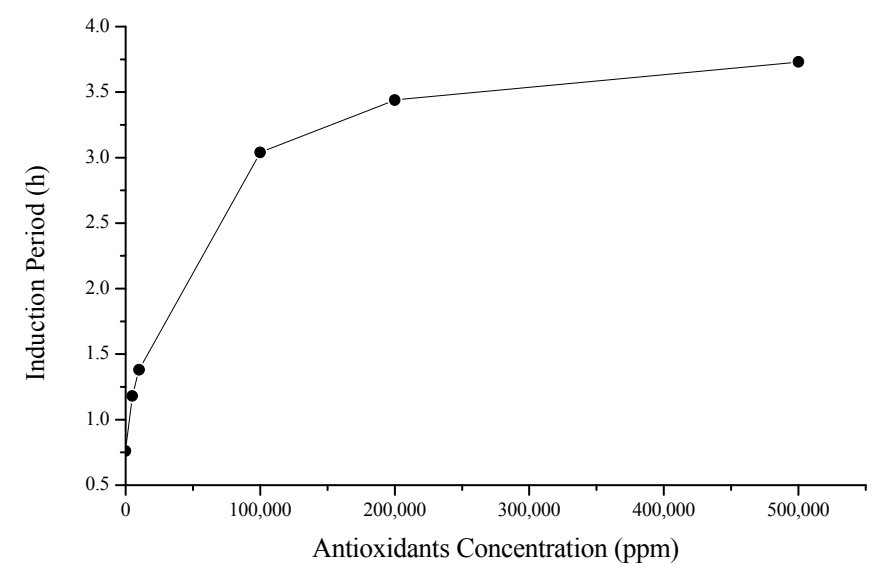

Figure 9. Effect of concentration of CNSL in induction period of methyl biosiedel of B. glabra. 
Table 3. Induction periods obtained to the methyl biodiesel of B. glabra (MBBg) doped TBHQ, BHT or CNSL at different concentrations.

\begin{tabular}{ccccc}
\hline \multirow{2}{*}{ Concentration $(\mathbf{p p m})$} & \multicolumn{5}{c}{ Induction Period (h) } \\
\cline { 2 - 5 } & TBHQ & BHT & CNSL & MBBg \\
\hline 0 & - & - & - & 0.76 \\
100 & 1.16 & 1.07 & - & - \\
500 & 2.80 & 2.06 & - & - \\
2000 & 6.75 & 6.41 & - & - \\
2500 & 8.43 & 8.06 & - & - \\
5000 & - & - & 1.18 & - \\
10,000 & - & - & 1.38 & - \\
100,000 & - & - & 3.04 & - \\
200,000 & - & - & 3.44 & - \\
500,000 & - & - & 3.73 & - \\
\hline
\end{tabular}

\section{Materials and Methods}

\subsection{Instrumentation}

Automatic hydrometer Anton Paar DMA 4500, viscometer Quimis ${ }^{\circledR}$, Rancimat Metrohm 743. Water and sediment were measured in an apparatus Benchmark 2000, of Koehler Instrument Company, Inc. (Holtsville, NY, USA); the bright point was determined in apparatus of vessel closed Pensky Martens APM-7 (Anton Paar Brazil Ltda, São Paulo, Brazil); corrosiveness to copper was in Petrotest ${ }^{\circledR}$ equipment (Petrotes Instruments GmbH \& Co. KG, Berlin, Germany); and, the Filter plugging point at cold was measured in Tanaka Scientific Limited AFP-102 (Tanaka Scientific Limited, Tokyo, Japan). The percentage of free and total glycerin, mono- di- and triacylglycerols were obtained on a gas chromatograph with a flame ionization detector GC-FID Varian 3800 (Varian, San Diego, CA, USA) and the methanol content by GC-FID coupled to static headspace, Varian 3900.

The methyl esters were analyzed in GC-FID, GC17A model, equipment Shimadzu with SELECT FAME column, Varian, and on a gas chromatograph GC17A model, with mass detector (GC-MS) QP5000, Shimadzu, column: SP 2560, SUPELCO. The NMR analysis were obtained in the spectrometer Varian Inova 500 (Center for NMR Spectroscopy, Pullman, WA, USA); the infrared analysis in Nicolet, Impact 400 (Nicolet Impact listings on LabX, Markham, Ontario, CA, USA), and thermogravimetric analysis in thermogravimetric balance.

\subsection{Plant Material}

Almonds of Bombacopsis glabra (Pasq.) Robyns were collected in in June 2003 in Brasilia-DF and stored in paper bags at room temperature. Dr. Carolyn Elinore Barnes of the University of Brasilia-UnB performed the botanical identification and the voucher specimen was deposited in the Herbarium of UnB in the UB 76691 number.

\subsection{Extraction and Degumming of Oil for Obtaining Biodiesel}

Samples of almonds of B. glabra, after being crushed, were submitted to extraction with hexane by $24 \mathrm{~h}$ at room temperature [7]. The oil obtained was degummed with $\mathrm{H}_{3} \mathrm{PO}_{4}$ [27]. The oil was preheated to below $60^{\circ} \mathrm{C}$, where $0.1 \%$ phosphoric acid (based on the mass of oil used) and $\mathrm{NaOH}$ solution $(8 \%)$, sufficient to neutralize $70-90 \%$ of the acid added. Then, $2 \%$ water was added, with subsequent heating and formation/decanting of the first gums, which were separated. The latter procedure was repeated, now with $3 \%$ water, to remove the remaining gums. The oil was dried with anhydrous sodium sulfate. 


\subsection{Synthesis of Biodiesel, TLC and ${ }^{1} H-N M R$ Analysis}

The degummed oil with $\mathrm{H}_{3} \mathrm{PO}_{4}$ was converted into biodiesel using the alkaline transesterification reaction. Sodium hydroxide was dissolved in methanol and added to the oil in weight ratios of 100:20 (oil:MeOH) [1,20]. Values $\mathrm{NaOH}$ used in this process were $0.5,0.75$, and $1.0 \%$ in relation to the oil. The mixture was kept under agitation at room temperature for $1 \mathrm{~h} \mathrm{[36-38],} \mathrm{posteriorly} \mathrm{it} \mathrm{was}$ transferred to a separating funnel and the methyl esters were separated from glycerol, washed with water, and dehumidified at $100{ }^{\circ} \mathrm{C}$. The biodiesel obtained was analyzed by TLC of silica gel, eluting with hexane-AcOEt (95:5), and iodine vapor as a dyeing reagent. The reaction yield was calculated for the expression: Yield $(\%)=($ mass of biodiesel $/$ oil mass $) \times 100$.

The conversion percentage of triacylglycerols into methyl esters was determined by GC, as well as by the analysis of the ${ }^{1} \mathrm{H}-\mathrm{NMR}$ spectrum from biodiesel dissolved in $\mathrm{CDCl}_{3}$ using the following expression: $\mathrm{C}=100 \times 2 \mathrm{~A}_{\mathrm{CH}_{3}} / 3 \mathrm{~A}_{\mathrm{CH}_{2}}$, where $\mathrm{C}=\%$ conversion, $\mathrm{A}_{\mathrm{CH}_{3}}=$ integration area of the signal at $\delta 3.7$ of methoxyl hydrogens and $\mathrm{A}_{\mathrm{CH}_{2}}=$ integration area of the signal at $\delta 2.3$ from methylene hydrogens $\alpha$-carbonyl of methyl esters and triacylglycerol [39].

\subsection{Physicochemical Characterization, Infrared and Thermogravimetric Analysis of Biodiesel}

The physicochemical analysis of biodiesel included: specific mass, kinematic viscosity, water and sediments, bright point, corrosiveness to copper, cold filter plugging point (CFPP), total and free glycerin, mono, di and triacylglycerol, methanol, and oxidation stability were realized according to the standards of the American Society of Testing and Materials (ASTM) and Européen de Normalisation Committee (CEN) as indicated by Resolution 45/2014 of the National Agency of Petroleum, Natural Gas and Biofuels (ANP) [23]. The acid value of biodiesel was determined according to the Analytical standards of the Institute Adolfo Lutz [36]. The viscosity of the biodiesel was performed by the method (ASTM D445).

The infrared spectra of the degummed oil and biodiesel were obtained in the region of $4000-400 \mathrm{~cm}^{-1}, \mathrm{KBr}$ shares.

The TG/DTG curves of oil extracted with hexane at room temperature, of degummed oil, and biodiesel were obtained in a temperature range of $30^{\circ} \mathrm{C}$ to $600^{\circ} \mathrm{C}$ at a heating rate of $10^{\circ} \mathrm{C} / \mathrm{min}$, in a nitrogen atmosphere with a flow rate of $50 \mathrm{~mL} / \mathrm{min}$ using an aluminum pan with a hole approximately $0.5 \mathrm{~mm}$ in the cap in diameter. The loss of sample mass was determined as the difference between the initial and final mass. The boiling point (temperature "onset") was considered as the point of intersection of the tangent of mass loss slope with the initial baseline. The product software was used to draw the tangent lines and record the boiling temperature $[25,26]$.

\subsection{Tests for Oxidation Stability}

The oxidation stability was measured according to EN 14112, where samples of $3 \mathrm{~g}$ were analyzed under heating at $110{ }^{\circ} \mathrm{C}$ and a constant airflow of $10 \mathrm{~L} \mathrm{~h}^{-1}$. In Rancimat, the airflow passes through the sample and subsequently bubbled into a flask containing deionized water, dragging the volatile carboxylic acids (degradation product) which solubilize and increase the conductivity of the water. The response elicited is a curve of electrical conductivity vs. time, in which two tangents intersect at a point, corresponding in time scale, the induction period, or oxidation stability [40].

The methyl biodiesel obtained was submitted to treatment with two synthetic antioxidants, TBHQ and BHT, and one of natural source, cashew nut shell liquid (CNSL) in concentrations: 100, 500, 2000, 2500, 5000, 10,000, 100,000, 200,000, and 500,000 ppm.

\subsection{Statistical Analysis}

With the exception of some physicochemical parameters, other analyzes were performed in triplicate, and presented the mean and standard deviation of the measurements. 


\section{Conclusions}

In this study, Bombacopsis glabra oil, which was extracted at room temperature and degummed with $\mathrm{H}_{3} \mathrm{PO}_{4}$, presented an acidity level suitable for conversion into biodiesel.

Methyl biodiesel was obtained for the first time from B. glabra oil through the transesterification process, using the base catalyst $(\mathrm{NaOH})$ with the superb conversion efficiency of triacylglycerols to methyl ester (more than $90 \%$ was obtained).

The physico-chemical parameters of biodiesel were in accordance with the limits established by ANP Resolution 45/2014, except for oxidation stability, which was corrected with the addition of antioxidants such as TBHQ and BHT.

The oil of B. glabra proved suitable for the preparation of biodiesel, allowing this species to be included among the oleaginous without technological dominion, such as: "babaçu" (Orbignya phalerata), "macaúba" (Acrocomia intumescens), and "tucum" (Bactris setosa).

The oil of B. glabra is a important oil for biodiesel production because it is not competes with edible oils due the presence of cyclopropenoid fatty acid, although some people eat their almonds.

Acknowledgments: Carolyn Elinore Barnes of the University of Brasília for the botanical identification of the species. The Laboratory of Brazil Ecodiesel Associate to Research and Development/Eusébio-CE for the availability of equipment necessary for the physicochemical characterization of biodiesel. To CENAUREMN/UFC and NuBBe/UNESP/Araraquara-SP by NMR spectra. LAPETRO-UFPI by TG analysis. CNPq, CAPES and FINEP for scholarships and financial support and to teacher Cecelia Paz for reviewing the English and grammar.

Author Contributions: Experimental works: Francisca Diana da Silva Araújo and Maria das Dores B. Sousa. Contributed to the experimental design and thoroughly revised the paper: Mariana Helena Chaves. Revised the paper according to the reviewer comments: Carla Verônica Rodart de Moura. Contributed to the translation of the manuscript: Soane Kaline Moraes Chaves. Donation of almonds from B. glabra and idealizer of work: Luimar José Tozetto. Collected and passed the almonds and oil analysis: Sabria Aued-Pimentel and Miriam Solange Fernandes Caruso. Preparing the manuscript: Antonio do Nascimento Cavalcante and Mariana Helena Chaves.

Conflicts of Interest: The authors declare no conflict of interest.

\section{References}

1. Lima, J.R.O.; Silva, R.B.; Silva, C.C.M.; Santos, L.S.S.; Santos, J.R., Jr.; Moura, E.M.; Moura, C.V.R. Biodiesel de babaçu (Orbignya sp.) obtido por via etanólica. Quim. Nova 2007, 30, 600-603. [CrossRef]

2. Rinaldi, R.; Garcia, C.; Marciniuk, A.V.R.; Schuchardt, U. Síntese de biodiesel: Uma proposta contextualizada de experimento para laboratório de Química geral. Quim. Nova 2007, 30, 1364-1380. [CrossRef]

3. Pereira, R.G.; Oliveira, C.D.; Oliveira, J.L.; Oliveira, P.C.P.; Fellows, C.E.; Piamba, O.E. Exhaust emissions and electric energy generation in a stationary engine using blends of biodiesel and soybean biodiesel. Renew. Energy 2007, 32, 2453-2460. [CrossRef]

4. Paula, V.F.; Barbosa, L.C.A.; Errington, W.; Howard, O.W.; Cruz, M.P. Chemical constituents from Bombacopsis glabra (Pasq) A. Robyns: Complete ${ }^{1} \mathrm{H}$ and ${ }^{13} \mathrm{C}$ NMR assignments and $\mathrm{X}$ ray structure of 5-hidroxy-3,6,7,8,4' -pentamethoxyflavone. J. Braz. Chem. Soc. 2002, 13, 276-280. [CrossRef]

5. Nyffeler, R.; Bayen, C.; Alverson, W.S.; Yen, A.; Whitlock, B.A.; Chase, M.W.; Baum, D.A. Phylogenetic analysis of the Malvadendrina clade (Malvaceae s.1.) based on plastid DNA sequences. Org. Divers. Evol. 2005, 5, 109-123. [CrossRef]

6. Pospíšil, F.; Hrachová, B. Bombacopsis glabra (Pasq.) Robyns: A promising oil-bearing crop for the Socialist Republic of Vietnam. Agric. Trop. Subtrop. 1987, 20, 127-142.

7. Chaves, M.H.; Araújo, F.D.S.; Moura, C.V.R.; Tozetto, L.J.; Aued-Pimentel, S.; Caruso, M.S.F. Chemical Characterization and Stability of the Bombacopsis glabra Nut Oil. Food Public Health 2012, 2, 104. [CrossRef]

8. Scalon, S.P.Q.; Mussury, R.M.; Rigoni, M.R.; Scalon Filho, H. Crescimento inicial de mudas de Bombacopsis glabra (Pasq.) A. Robyns sob condição de sombreamento. Rev. Árvore 2003, 27, 753-758. [CrossRef]

9. Piccolo, A.L.G. Sobre o fruto, semente e estágios iniciais de desenvolvimento de Bombacopsis glabra (Pasq.) A. Robyns. Sér. Bot. 1981, 5, 1-4.

10. Breyne, H. Bombacopsis glabra (Pasquale) A. Robyns (Bombacaceae) espèce utile pour l'élevage et pour l'alimentation humaine. Tropicultura 1983, 1, 78-85. 
11. Vickery, J.R. The fatty acid composition of seed oils from ten plant families with particular reference to cyclopropene and dihydrosterculic acids. J. Am. Oil Chem. Soc. 1980, 57, 87-91. [CrossRef]

12. Chaves, M.H.; Barbosa, A.S.; Moita Neto, J.M.; Aued-Pimentel, S.; Lago, J.H.G. Caracterização química do óleo da amêndoa de Sterculia striata St. Hil. et Naud. Quim. Nova 2004, 27, 404-408. [CrossRef]

13. Aued-Pimentel, S.; Lago, J.H.G.; Chaves, M.H.; Kumagai, E.E. Evaluation of a methylation procedure to determine cyclopropenoids fatty acids from Sterculia striata St. Hil. Nauds seed oil. J. Chromatogr. A 2004, 1054, 235-239. [CrossRef] [PubMed]

14. Dewick, P.M. Medicinal Natural Products: A Biosynthetic Approach, 3nd ed.; Jonh Wiley and Sons: New York, NY, USA, 2009.

15. Gomes Filho, J.C.; Peiter, A.S.; Pimentel, W.R.O.; Soletti, J.I.; Carvalho, S.H.V.; Meili, L. Biodiesel production from Sterculia striata oil by ethyl transesterification method. Ind. Crops Prod. 2015, 74, 767-772. [CrossRef]

16. Cornelius, J.A.; Hammonds, T.W.; Shone, G.G. The composition of Bombacopsis glabra seed oil. J. Sci. Food Agric. 1965, 16, 170-172. [CrossRef]

17. Zaidul, I.S.M.; Nik Norulaini, N.A.; Mohd Omar, A.K.; Smith, R.L., Jr. Blending of supercritical carbon dioxide $\left(\mathrm{SC}-\mathrm{CO}_{2}\right)$ extracted palm kernel oil fractions and palm oil to obtain cocoa butter replacers. J. Food Eng. 2007, 78, 1397-1409. [CrossRef]

18. Tangsathitkulchai, C.; Sittichaitaweekul, Y.; Tangsathitkulchai, M. Temperature Effect on the Viscosities of Palm Oil and Coconut Oil Blended with Diesel Oil. J. Am. Oil Chem. Soc. 2004, 81, 401-405. [CrossRef]

19. Giannelos, P.N.; Zannikos, F.; Stournas, S.; Lois, E.; Anastopoulos, G. Tobacco seed oil as an alternative diesel fuel: Physical and chemical properties. Ind. Crops Prod. 2002, 16, 1-9. [CrossRef]

20. Conceição, M.M.; Candeia, R.A.; Silva, F.C.; Bezerra, A.F.; Fernandes, V.J.; Souza, A.G. Thermoanalytical characterization of castor oil biodiesel. Renew. Sustain. Energy Rev. 2007, 11, 964-975. [CrossRef]

21. Dermibaş, A. A direct route to the calculation of heating values of liquid fuels by using their density and viscosity measurements. Energy Convers. Manag. 2000, 41, 1609-1614.

22. Geris, R.; Santos, N.A.C.; Amaral, B.A.; Maia, I.S.; Castro, V.D.; Carvalho, J.R.M. Biodiesel de soja-Reação de transesterificação para aulas práticas de Química Orgânica. Quim. Nova 2007, 30, 1369-1373. [CrossRef]

23. RESOLUÇÃO ANP No 45, de 25.8.2014-DOU 26.8.2014. Available online: http://nxt.anp.gov.br/nxt/ gateway.dll/leg/resolucoes_anp/2014/agosto/ranp\%2045\%20-\%202014.xml (accessed on January 2016).

24. Silverstein, R.M.; Webster, F.X.; Kiemle, D.J. Identificação Espectrométrica de Compostos Orgânicos, 7th ed.; LTC: Rio de Janeiro, Brazil, 2006.

25. Goodrum, J.W. Volatility and boiling points of biodiesel from vegetable oils and tallow. Biomass Bioenergy 2002, 22, 205-211. [CrossRef]

26. Goodrum, J.W.; Geller, D.P. Rapid thermogravimetric measurements of boiling points and vapor pressure of saturated medium- and long-chain triglycerides. Bioresour. Technol. 2002, 84, 75-80. [CrossRef]

27. Moretto, E.; Fett, R. Tecnologia de Óleos e Gorduras Vegetais na Indústria de Alimento; Livraria Varela: São Paulo, Brazil, 1998.

28. Araújo, F.D.S.; Araújo, I.C.; Costa, I.C.G.; Moura, C.V.R.; Chaves, M.H.; Araújo, E.C.E. Study of degumming process and evaluation of oxidative stability of methyl and ethyl biodiesel of Jatropha curcas L. oil from three different Brazilian states. Renew. Energy 2014, 71, 495-501. [CrossRef]

29. Domingos, A.K.; Saad, E.B.; Vechiatto, W.W.D.; Wilhelm, H.M.; Ramos, L.P. The influence of BHA e TBHQ on the oxidation stability of soybean oil ethyl esters (biodiesel). J. Braz. Chem. Soc. 2007, 18, 416-423. [CrossRef]

30. Ramalho, V.C.; Jorge, N. Antioxidantes utilizados em óleos, gorduras e alimentos gordurosos. Quim. Nova 2006, 29, 755-760. [CrossRef]

31. Dunn, R.O. Effect of antioxidants on the oxidative stability of methyl soyate (biodiesel). Fuel Process. Technol. 2005, 86, 1017-1085. [CrossRef]

32. Liang, Y.C.; May, C.Y.; Foon, C.S.; Ngan, M.A.; Hock, C.C.; Basiron, Y. The effect of natural and synthetic antioxidants on the oxidative stability of palm diesel. Fuel 2006, 85, 867-870. [CrossRef]

33. Loh, S.L.; Chew, S.M.; Choo, Y.M. Oxidative stability and storage behavior of fatty methyl esters derived from used palm oil. J. Am. Oil Chem. Soc. 2006, 83, 947-952. [CrossRef]

34. Sarin, R.; Sharma, M.; Sinharay, S.; Malhotra, R.K. Jatropha-palm biodiesel blends: An optimum mix for Asia. Fuel 2007, 86, 1365-1371. [CrossRef] 
35. Silva, M.C.D.; Conceição, M.M.; Fernandes, V.J., Jr.; Santos, I.M.G.; Souza, A.G. Avaliação do efeito antioxidante do líquido da castanha de caju (LCC) em óleo e biodiesel de mamona. In Congresso da Rede Brasileira de Tecnologia de Biodiesel; Anais; MCT/ABIPTI: Brasília, Brazil, 2006; Volume 1, pp. 192-195.

36. Instituto Adolfo Lutz. Normas Analíticas do Instituto Adolfo Lutz. Métodos Químicos e Físicos Para Análise de Alimentos, 3rd ed.; IMESP: São Paulo, Brazil, 1985.

37. Kumar, M.S.; Ramesh, A.; Nagalingam, B. An experimental comparison of methods to use methanol and Jatropha oil in a compression ignition engine. Biomass Bioenergy 2003, 25, 309-318. [CrossRef]

38. Vicente, G.; Martinez, M.; Aracil, J. Optimisation of integrated biodiesel production. Part I. A study of the biodiesel purity and yield. Bioresour. Technol. 2006, 98, 1724-1733. [CrossRef] [PubMed]

39. Meher, L.C.; Sagar, D.V.; Naik, S.N. Technical aspects of biodiesel production by transesterification-A review. Renew. Sustain. Energy Rev. 2006, 10, 248-268. [CrossRef]

40. Antoniassi, R. Métodos de avaliação da estabilidade oxidativa de óleos e gorduras; The Center for Ethics, Philosophy and Public Affairs (CEPPA): Curitiba, Brazil, 2001; Volume 19, pp. 353-380.

(C) 2017 by the authors. Licensee MDPI, Basel, Switzerland. This article is an open access article distributed under the terms and conditions of the Creative Commons Attribution (CC BY) license (http:/ / creativecommons.org/licenses/by/4.0/). 